\title{
Kísérleti fröccsöntő szerszám tervezése mikrostrukturált formaadó felületek vizsgálatához
}

\section{Design of an Experimental Injection Moulding Tool for Testing Microstructured Cavity Surfaces}

\author{
Kun Krisztián \\ Neumann János Egyetem, GAMF Müszaki és Informatikai Kar, Innovatív Jármüvek és Anyagok Tanszék, \\ Kecskemét, Magyarország, kun.krisztian@gamf.uni-neumann.hu
}

\begin{abstract}
This research is based on the impact assessment of the active element of injection moulding tools. The quality of the tool surface has a significant effect on the filling and cooling efficiency. Our goal is to create a uniform structure on the cavity's surface that results in a high degree of orientation during the injection moulding process. A special experimental tool is needed for the research. Our design was based on the results of previous experimental research and preliminary criteria. The design was based on the size and position tolerances of the A side of the tool. As the previous study has shown, there are three main points to consider when designing an experimental moulding tool. These are the applied manufacturing technology, Design for Assembly, and the expansion of the measurement possibilities by using different sensors. The small beam size of the femtosecond laser also allows the machining of microscopic-sized details, a technology used to structure the cavity surface. The success of this was analyzed by microscopic examination.
\end{abstract}

Keywords: surface structure, femtosecond laser, injection moulding, surface mapping, insert.

\section{Összefoglalás}

A kutatás a fröccsöntő szerszámok aktív elemének hatásvizsgálatára irányul. A szerszámfelület minősége jelentős hatással van a kitöltésre és a hűtés hatékonyságára. A formaadó felületen olyan egységes, strukturált felszín létrehozását végeztük, amely nagymértékű orientációt eredményez a fröccsöntési folyamat során. A kutatáshoz egy speciális kísérleti szerszámra volt szükség. Ennek tervezését egy korábbi kísérlet eredményeire és előzetes kritériumokra alapoztuk. A tervezés a szerszámban eredetileg is megtalálható álló oldali formabetét méret- és helyzettűréseit alapul véve történt. Ahogyan azt a korábbi vizsgálat is mutatta, három fő szempontot kellett figyelembe venni a szerszám tervezése kapcsán. Ezek az alkalmazott gyártástechnológia, a könnyen szerelhető konstrukció, illetve a mérési lehetőségek kibővítése különböző szenzorok alkalmazásával. A femtoszekundumos lézer kis sugármérete lehetőséget adott a mikroméretű részletek kimunkálására, amely eljárást a formaadó felület strukturálására használtunk. Ennek sikerességét mikroszkópi vizsgálattal elemeztük.

Kulcsszavak: felületszerkezet, femtoszekundumos lézer, fröccsöntés, leképezés, formaadó betét.

\section{Bevezetés}

A fröccsöntési folyamat során a termék keresztmetszetét vizsgálva megállapítható, hogy az egyes szegmensekben eltérő mértékű molekulaorientáció jön létre. Polimer ömledék izotermikus áramlása esetén a fal melletti rétegek sebessége a csatorna közepén áramlókéhoz képest kisebb lesz a súrlódás következtében. Hosszú molekulájú anyagok áramlásánál azok nem állhatnak be az áramlási irányra merőlegesen, hanem a makromolekula párhuzamosan orientálódik az ömledékáramlással. A sebességprofilból adódik, hogy a fal melletti orientáció mértéke nagyobb, mint a csatorna közepén. A folyamat során burkolóhár- 
tya fejtődik rá a szerszám falára, amely tovább hül. Az ömledék állapotú és a már megszilárdult rétegek között nyíróhatás hozza létre a nyírt orientált réteget. A termék közepe felé haladva kevésbé orientált vagy orientálatlan rétegeket találunk. Ezek a zónák átmenetiek, nincs közöttük éles határ. Mivel a szerszámfelület minősége jelentős hatással van a kitöltésre és a hütés hatékonyságára, azt feltételezhetjük, hogy az eltérő orientációval rendelkező rétegek aránya módosul, ezáltal megváltoznak a fröccsöntött termékek mechanikai tulajdonságai is. A mechanikai tulajdonságok vizsgálatára egy speciális kísérleti fröccsöntő szerszámot terveztünk [1, 2].

\subsection{A forgácsolt felületü kísérleti fröccsön- tő szerszám bemutatása}

A kísérlet az aktív elemek vizsgálatára irányult, így a tervezés a szerszámban eredetileg is megtalálható álló oldali formabetét méret- és helyzettüréseit alapul véve történt. Két olyan, egymástól eltérő felületi mintázatot kívántunk létrehozni, amelyek nagymértékű orientációt eredményeznek a fröccsöntési folyamat során. Az ömledék folyásirányára merőleges, illetve azzal párhuzamos hornyot alakítottunk ki a szerszámbetét dolgozó felületének két oldalán. A hornyok tervezett mélysége $100 \mu \mathrm{m}$ (1. ábra) [3, 4, 7].

\subsubsection{A gyártási módszer kiválasztása}

Alkalmazott gyártási eljárásként forgácsolást választottunk a mintázatok létrehozására. A forgácsolás $30^{\circ}$-os csúcsszögü keményfém-gravírozó tüvel történt, amelynek 0,2 mm a csúcslekerekítése, továbbá TiN-bevonattal ellátott. A gravírozás során a pályák hossza miatt a szerszám fokozott kopásnak van kitéve. Típusa: SKU311611 (2. ábra) [3-5].

\subsubsection{A megmunkálás utáni vizsgálat}

A geometriai peremfeltételek rögzítését követően legyártottuk a tervezett pályákat, majd azokat Mitutoyo QuickVision Elf Pro digitális mikroszkóp segítségével elemeztük. Az így kapott felvételeken jól kivehetők a kialakított hornyok makro- és mikrogeometriai jellemzői, például a hornyok szélessége és érdessége (3. ábra) [3, 4, 6].

\subsubsection{A betéten kialakított mintázat vizsgálata kontúrmérő berendezéssel}

A párhuzamos és merőleges pályákat 3-3 részre osztva történt a kontúrmérés 3,5 mm-es vizsgálati hosszon. A szakaszokat a pálya kezdetén, közepén és végén vettük fel. Ennek segítségével a szerszámkopásból adódó magasságbeli eltérések kimutathatók voltak (4. ábra).

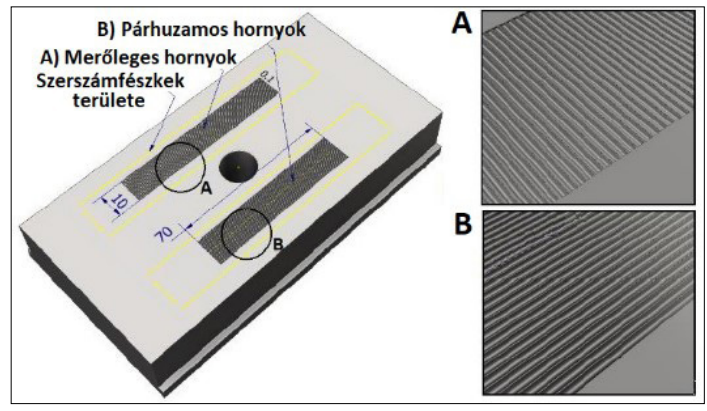

1. ábra. Az aktív elemre tervezett felületi mintázat [3]

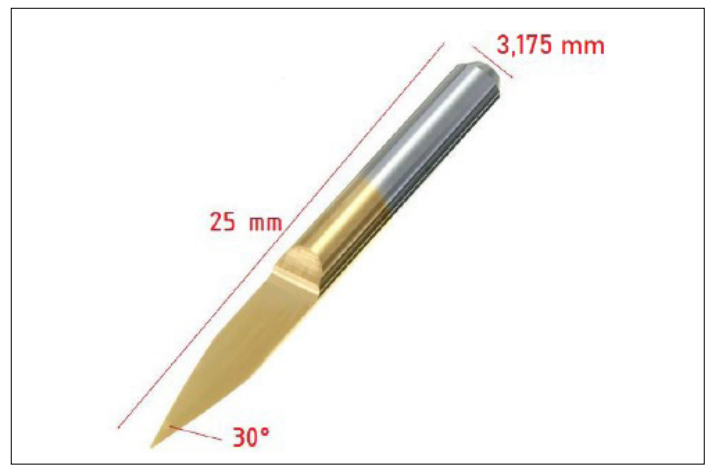

2. ábra. Keményfém-gravírozó tü TiN-bevonattal [3]
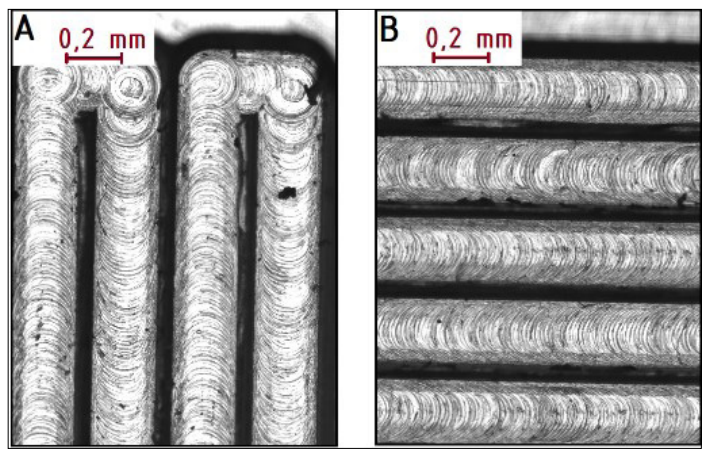

3. ábra. A merőleges (A) és párhuzamos hornyok (B) mikroszkópi felvételei [3]

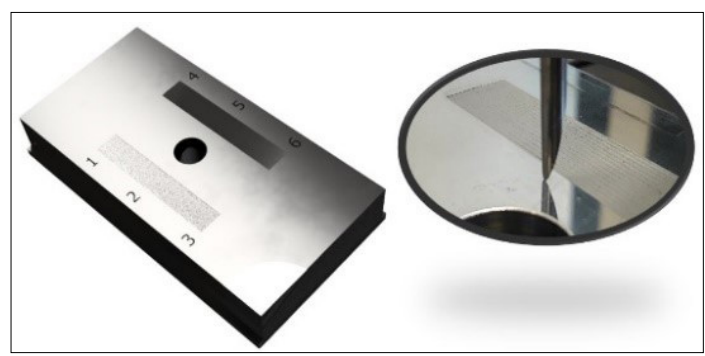

4. ábra. A kontúrmérés vizsgálati pontjainak elhelyezkedése a szerszámbetét felületén [3] 
Már a mikroszkópi képeken is látható volt a különbség a gravírozott pályák között, amit a kontúrmérés is igazolt. A gravírozással létrehozott hornyoknál, geometriájukat tekintve szabályos rendezettség figyelhető meg, ezzel szemben a párhuzamos és merőleges pályák profiljai nem mutattak számottevő különbségeket. A szerszámkopás átlagos értéke 0,02 mm-re tehető. Az 5. ábrán jól megfigyelhető, hogy a szerszámpályák távolsága közelíti az előre programozott értéket $(0,34 \mathrm{~mm})[3,4,8]$.

\subsubsection{A kísérlet értékelése}

Ahhoz, hogy a tervezett felületelemek nagyobb egyezőséget mutassanak, gondos technológiai és geometriai előtervezés szükséges. Jól szemléltették ezt a kontúrmérés eredményei is. Technológiai szempontból a forgácsolást fel kell váltani egy olyan eljárással, amely mindenhol egységes textúrát képes létrehozni. Emellett egy olyan szerszám megalkotása a cél, amelyen a mintázatok szerelhető betéteken keresztül rögzíthetők a formaüregre, ezzel megkönnyítve különböző mintázatok cseréjét, azok hatásának vizsgálatát. További cél, hogy a gyártás során a folyamatparaméterek diagnosztizálását hőmérséklet- és nyomásszenzorokkal nyomon tudjuk követni.

\section{Kísérleti fröccsöntő szerszám terve- zése}

\subsection{A tervezést befolyásoló tényezők}

Ahogyan a korábbi vizsgálat is mutatta, három fő szempontot kell figyelembe venni a szerszám tervezése kapcsán: az alkalmazott gyártási eljárást, a könnyű szerelhetőséget, illetve a mérési lehetőségek kibővítését különböző szenzorok alkalmazásával.

\subsubsection{Gyártás femtoszekundumos lézerrel}

A lézeres anyagmegmunkálási eljárások közös jellemzője, hogy az eltávolított anyag mennyisége a technológia függvényében állandó, szemben a forgácsolásnál jelentkező szerszámkopással. A femtoszekundumos lézer kis sugármérete lehetőséget ad mikroméretű részletek kimunkálására is, valamint olyan rövid impulzusokat generál, amelyek nem hagynak termikus nyomokat a megmunkált alkatrészen (6. ábra). A megmunkált anyag az abláció során eróziós folyamaton megy keresztül. Jelen kutatásban célunk egy olyan egységes felület létrehozása, amely mindenhol azonos mélységű pályát tartalmaz. A gyártás során olyan lehetséges problémákra is nagy hangsúlyt kell fektetni, mint a plazmaképződés és az oxidáció elkerülése, illetve a hőhatásövezet méretének minimalizálása [9, 10].

A rendelkezésünkre álló berendezés egy Monaco 1035-80-40 típusú ipari femtoszekundumos lézer (7. ábra), amely egy LINOS F-Theta-Ronar típusú szkenneroptikával van ellátva. A lézer $80 \mu \mathrm{J} / \mathrm{impulzus}$ energia leadására képes 1035 nanométeres hullámhossz mellett. A maximálisan beállítható impulzushossz 277 fs [F].

$\mathrm{Az}$ alkalmazott lézerberendezés pontos technikai jellemzőit az 1. táblázat tartalmazza.

1. táblázat. Monaco 1035-80-40 lézer paraméterei [11]

\begin{tabular}{|l|c|}
\hline Átlagteljesítmény & $40 \mathrm{~W}$ \\
\hline Impulzusenergia & $80 \mu \mathrm{J}(500 \mathrm{kHz}-\mathrm{en})$ \\
\hline Frekvenciatartomány & $188 \mathrm{kHz}-50 \mathrm{MHz}$ \\
\hline Hullámhossz & $1035 \pm 5 \mathrm{~nm}$ \\
\hline Impulzushossz & $<350 \mathrm{fs}$ \\
\hline Módus & TEM $00, \mathrm{M} 2<1,2$ \\
\hline
\end{tabular}

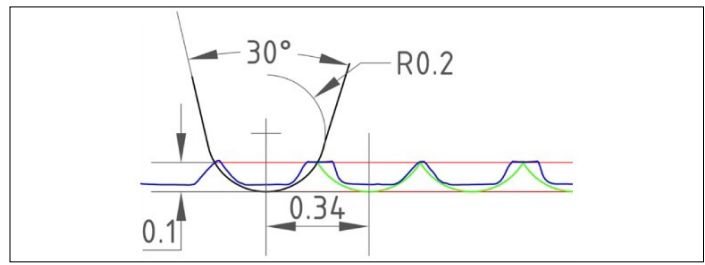

5. ábra. A hornyok méreteinek változása: zöld színnel a tervezett, kékkel a kialakult kontúr [3]

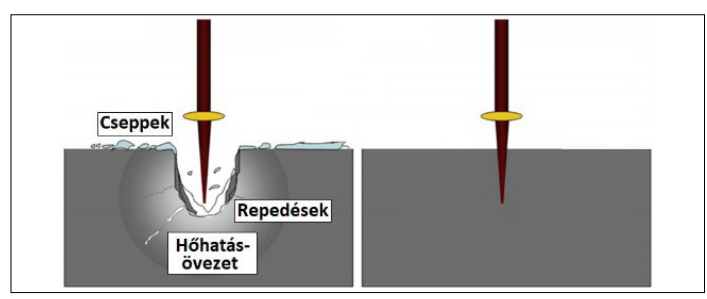

6. ábra. Hosszú impulzusú (balra) és rövid impulzusú lézerek (jobbra) hőhatásövezete [13]

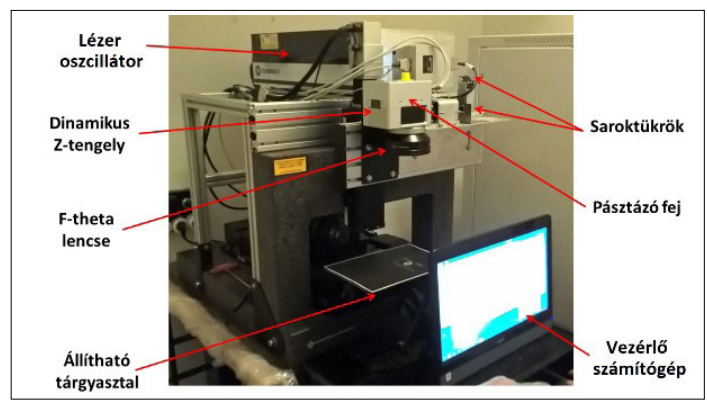

7. ábra. A femtoszekundumos lézerberendezés 


\subsubsection{A szerszámbetétek texturált felületének kialakítása}

Az új kísérleti szerszám esetében a texturált betétek a mozgó oldali szerszámfélben foglalnak helyet (8. ábra). A betétek rögzítéséért további két köszörült betét felel, amelyek csavarkötéssel kapcsolódnak a szerszámtesthez. A szerszám terméke két szabványos szakító próbatest, amelyek mechanikai vizsgálatokhoz alkalmazhatók.

A korábbi kutatásban két eltérő orientáltságú mintázatot hoztunk létre. A lézeres megmunkálásnak köszönhetően jó ismétlési pontossággal reprodukálhatjuk a különféle mintázatokat. A betét alapja $\mathrm{R}_{\mathrm{a}}=0,4 \mu \mathrm{m}$ felületi érdességre köszörült, M200 anyag jelű szerszámacél. A párhuzamos és merőleges minta mellett a továbbiakban célunk különféle raszterminták vizsgálata. A tervezett szerszám előnye, hogy a formalap két oldalán cserélhetők a különböző módon texturált betétek. A mechanikai vizsgálatok összehasonlító elemzéseihez készül továbbá egy $R_{a}=0,4 \mu \mathrm{m}$ érdességü köszörült felületű betét is. A betétek hasznos felülete $78 \times 10 \mathrm{~mm}$ (9. ábra).

\subsubsection{Szenzorok}

Az elektrorezisztív elven működő nyomásmérő szenzor beszerelésére kétféle módszer létezik: direkt és indirekt módszer. A direkt módszer esetében a szenzor szoros illesztéssel rögzíthető közvetlenül a formaüreghez. A folyamatos előfeszítés, karbantartás és szerelés befolyásolja a mérési pontosságot. A kísérleti szerszámhoz alkalmazott indirekt beszerelésnél egy fordított csap kerül be a kidobó csap mögé laza illesztéssel, így adja át a nyomásból származó erőt. Előnye, hogy sem előfeszítést, sem karbantartást nem igényel a szerszám teljes élettartama alatt. Az egzaktabb vizsgálati eredményekhez az ömledék-hőmérséklet mérésére további szenzorok alkalmazása javasolt [12].

\section{Eredmények}

A tervezést követően a gyártott betéteken femtoszekundumos lézerrel felületkezelést végeztünk, majd az így kapott mintázatot Mitutoyo QuickVision Elf Pro digitális mikroszkóppal vizsgáltuk. A hornyok tervezett méreteit a 10 . ábra szemlélteti.

A lézeres felületkezelés során kialakult „V” profilú hornyok létrejöttének (11. ábra) több oka is lehet:

A lézernyaláb TEM00 módusú, emiatt a nyaláb intenzitáseloszlása Gauss-eloszlást követ. Esetünkben a nyaláb középső részén a legnagyobb

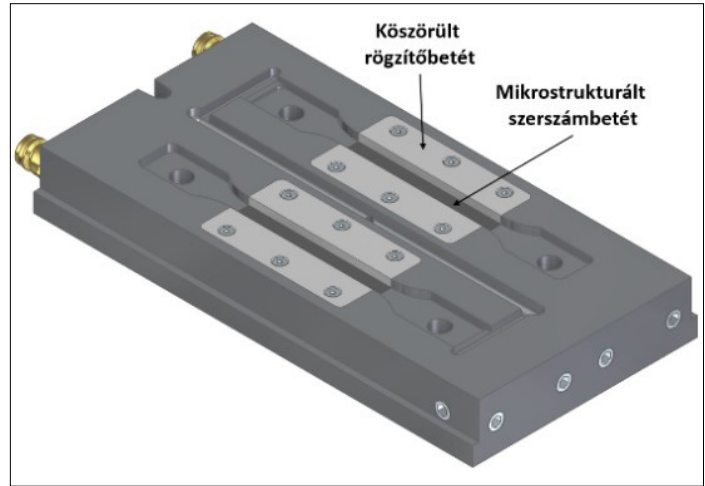

8. ábra. A tervezett kísérleti fröccsöntő szerszám

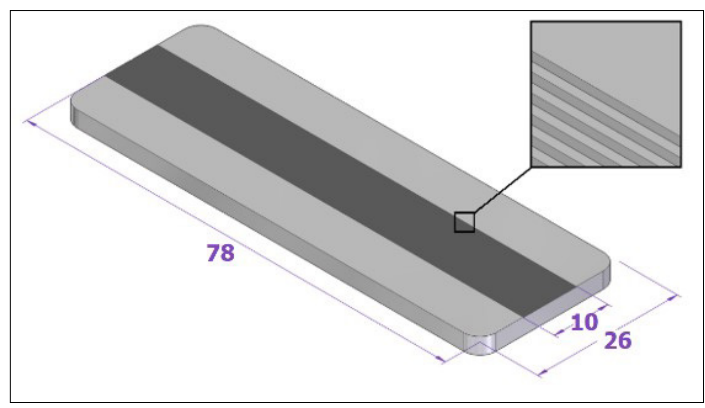

9. ábra. Párhuzamos hornyokkal ellátott szerszámbetét

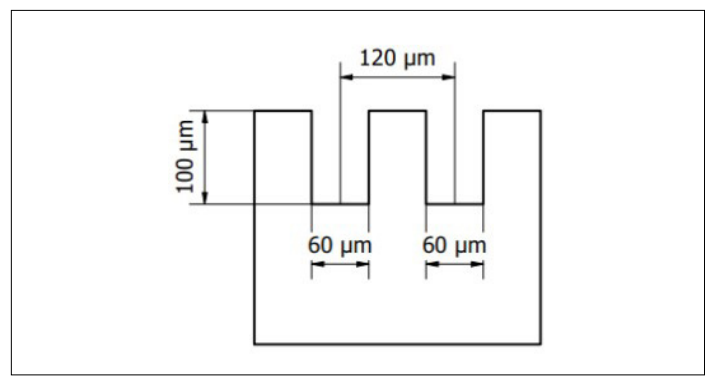

10. ábra. A hornyok tervezett méretei

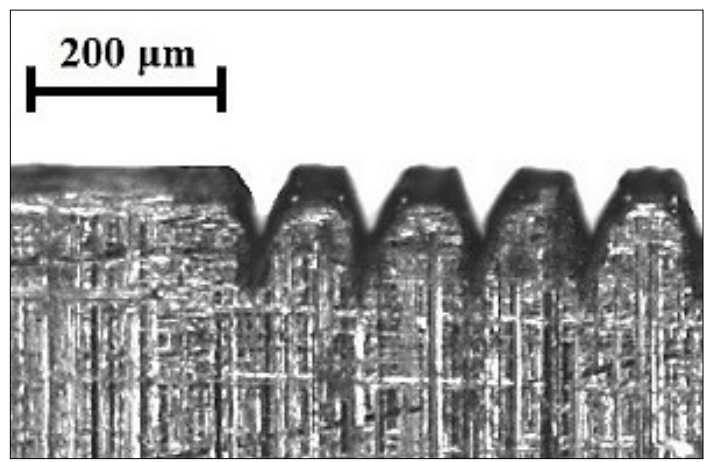

11. ábra. A felületi mintázat mikroszkópi képe a hornyokra merőleges metszetben 


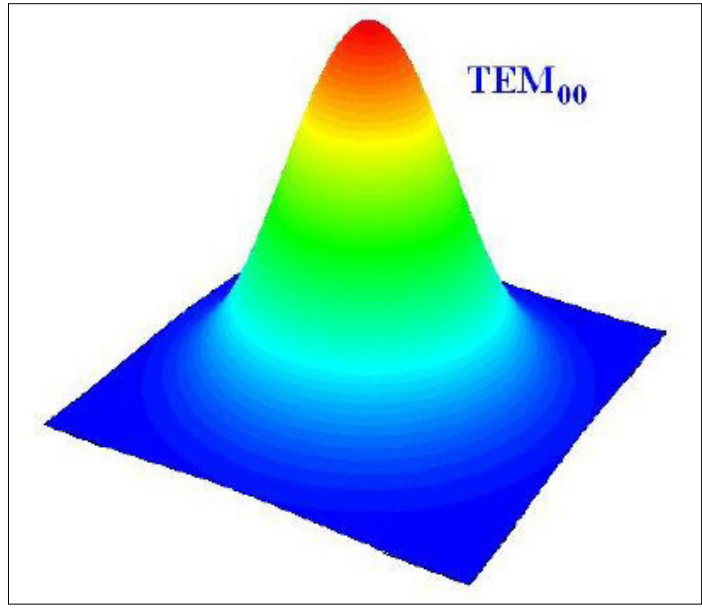

12. ábra. Monaco 1035-80-40 lézer Gauss-eloszlású nyaláb energiaeloszlása [11]

az intenzitás, attól kifelé az fokozatosan csökken, amit a 12. ábra szemléltet.

A tervezett mélység kialakítása érdekében a struktúrák többszöri pásztázással készültek. A dinamikus fókuszállítás során először a felszínre fókuszáltunk, ami $60 \mu \mathrm{m}$ széles csatornát alakított ki. A fókuszeltolást követően a csatornaszélesség $(60 \mu \mathrm{m})$ továbbra is állandó értékkel készült volna, viszont a nyaláb divergenciája miatt, a fókuszhelyzettől pozitív irányban (a nyalábderék fölött) is elértük az ablációs határt, ami tovább szélesítette a csatornát.

A csatornán belüli szóródott sugárzás további anyagot távolíthat el a felülethez közelebbi rétegekből a többszöri pásztázás miatt.

\section{Következtetések}

Polimer ömledék áramlása esetén a makromolekulák nem rendeződhetnek az áramlási irányra merőlegesen, hiszen így két végük különböző sebességgel mozogna. Ebből következik a makromolekuláknak az ömledékáram irányával párhuzamos orientációja. A súrlódás következtében a fal melletti rétegek sebessége kisebb. A sebességprofilból adódik, hogy a fal melletti párhuzamos orientáció mértéke nagyobb. A termék közepe felé haladva az orientáció párhuzamossága csökken. Korábbi kutatásokra alapozva, a fröccsöntés során a szerszám formaadó felületének felületi minősége hatással van a kitöltésre és a hütés hatékonyságára. Ez a jelenség az eltérő orientációjú rétegek arányát módosíthatja, megváltoztatva a fröccsöntött termékek mechanikai tulajdonságait.

Jelen kutatás eredményeként megterveztünk egy speciális kísérleti fröccsöntő szerszámot, melynek célja a molekulaorientáció nagymértékű befolyásolása a fröccsöntési folyamat során. Segítségével az előzetes vizsgálatok eredménye validálható, a kutatási terület tovább bővíthető. Az alkalmazott femtoszekumdumos lézerrel egységes felületi struktúra alkotható.

\section{Köszönetnyilvánítás}

Köszönettel tartozunk a kutatás támogatásáért, amely az EFOP-3.6.1-16-2016-00006 „A kutatási potenciál fejlesztése és bővítése a Neumann János Egyetemen” pályázat keretében valósult meg. A projekt a Magyar Állam és az Európai Unió támogatásával, az Európai Szociális Alap társfinanszírozásával, a Széchenyi 2020 program keretében valósul meg.

\section{Szakirodalmi hivatkozások}

[1] Pantani R., Sorrentino A., Speranza V., Titomanlio G.: Molecular orientation in injection molding: experiments and analysis. Rheologica acta, 43/2. (2004) 109-118.

https://doi.org/10.1007/s00397-003-0325-8

[2] Pósa M., Belina K., Boza P.: Amorf és kristályos polimerek mechanikai tulajdonságainak vizsgálata. Inter-Ing, Târgu Mureș, 2006. 69-72.

[3] Kun K., Boza P., Weltsch Z.: Polimer ömledék leképeződésének vizsgálata formaüreg felületi struktúráin. Gradus, 6/1. (2019) 192-198.

[4] Kun K., Boza P.: Investigation of inserts surface structures on injection moulded parts. In IOP Conference Series: Materials Science and Engineering, 448/1. (2018) 012052.

https://doi.org/10.1088/1757-899X/448/1/012052

[5] Fleischer J., Kotschenreuther J.: The manufacturing of micro molds by conventional and energyassisted processes. The International Journal of Advanced Manufacturing Technology, 33/1-2. (2007) 75-85.

https://doi.org/10.1007\%2Fs00170-006-0596-1

[6] Holthusen A. K., Riemer O., Schmütz J., Meier A.: Mold machining and injection molding of diffractive microstructures. Journal of Manufacturing Processes, 26. (2017) 290-294.

https://doi.org/10.1016/j.jmapro.2017.02.014

[7] Theilade U. A., Hansen H. N.: Surface microstructure replication in injection molding. The International Journal of Advanced Manufacturing Technology, 33/1. (2007) 157-166.

https://doi.org/10.1007/s00170-006-0732-y

[8] Pósa M., Belina K., Boza P., Szűcs A.: Examination of the effect of machining technology on the surface of injection moulding parts. Inter-Ing, TârguMures, 2005, 19-25.

[9] Temmler A., Willenborg E., Wissenbach K.: Design surfaces by laser remelting. Physics Procedia, 12. (2011) 419-430.

https://doi.org/10.1016/j.phpro.2011.03.053 
[10] Preußner J., Oeser S., Pfeiffer W., Temmler A., Willenborg E.: Microstructure and residual stresses of laser structured surfaces. In Advanced Materials Research, 996. (2014) 568-573.

https://doi.org/10.4028/www.scientific.net/ AMR.996.568

[11] Monaco: Industrial Femtosecond Laser adatlap https://dokumen.tips/documents/monaco-1035-edge-1035-industrial-femtosecond-laser-monaco-1035-is-an-industrial.html

(letöltve: 2021. 02. 15.)
[12] Cavity Eye: Szerszámnyomás mérés http://cavityeye.com/froccsontes-technologia (letöltve: 2021.02. 15.)

[13] J. Gergely: Átlátszó PMMA megmunkálása femtoszekundumos lézerrel. Gradus, 8/1. (2021) 219226.

https://doi.org/10.47833/2021.1.ENG.001 